\title{
Ethiopia: Changes from "People out Approach" Protected Area Management to Participatory Protected Area Management? Insight from Ethiopian Protected Areas
}

\author{
Derera Ketema Teressa \\ Department of Tourism and Hotel Management, College of Business and Economics, Arba Minch University
}

\begin{abstract}
The study examines protected area management changes in Ethiopia under different regimes. Being known by its oldest record of formalized conservation effort in Africa, protected area management, development and utilization policy and practice in Ethiopia has been subject to a series of paradigm changes since the establishment of Ethiopian Wild Life Organization in 1965. Drawing on a documentary analysis of legislation, published policy statements, commentaries and scholarly critiques, this paper argues that Ethiopian protected area management has undergone three significant paradigm shifts. Firstly, there was a shift from land lord and state owned protected area management with imperial political ideology to socialist protected areas management system. Then, there has been a new paradigm shift from socialist regime to the moderately decentralized protected area management policy with an attempt to allow community participation in the development, utilization and conservation of biodiversity.
\end{abstract}

Key Words: Ethiopia, Protected Area Management, participatory approach, people out approach

\section{Introduction}

Protected areas (PAs) are policy instruments for preservation and sustainable use of natural resources (Kelboro and Stellmacher, 2012); vital tool to achieve conservation and sustainable development (Du et al., 2015) with a growing acknowledgement of diversified expectation for protected areas (McCool et al, 2013). Despite exponential growth of PA in developing countries with a paradigm shift from biodiversity conservation to human welfare improvement (Naughton-Treves et.al, 2005). Consequently, the economic cost of global biodiversity loss is estimated to be $€ 14$ trillion by 2050 (Agence Française de Développement, 2014). Parks tend to live their own lives; they reshape and change the land use patterns and people surrounding it (Vedeld et al., 2012). As a desire to live on their ancestral land; to ensure food security; to some extent, exercise local economic, cultural and political autonomy is the main concern for preservation and conservation of traditional knowledge (Langton et al, 2005). Besides, protecting an outstanding nature and recognized services provided by nature for the benefit of human being is essential, especially, in developing country where the largest part of world biodiversity is found and people's livelihood is dependent on nature.

Throughout sub Saharan Africa, natural resources remain central to rural people's livelihoods shaped by their norms and customs in every form of resource usage being affected by government policies (Roe et al, 2009). However, indigenous African communities often developed complex resource management systems (Fabricius, 2004), as of other communities throughout the world (Ostrom, 1990). Moreover, biodiversity governance with fortress approach or state led was imposed by proponents of conservation in previous decades (Oates, 1999; Terborgh, and Soule, 1999) resulted in separation of man and nature and forceful displacement of local community (Agrawal and Redford, 2009). However, changes in protected area management are portrayed within the context of commotion occurred at different scales with a variety of actors experiencing and causing changes (Barber, Miller, \& Boness, 2004). Besides, participatory approach to conservation through park outreach activities, collaborative management and community conservation is gaining popularity (Adams and Hutton, 2007; Goldman, 2003; Cleaver, 1999). As a result, incorporating community's need and aspiration is very important as a result of paradigm shift from centralized protected area management to decentralized PA management in the international and national context.

Experiencing different conservation practices and challenges, the report of Ethiopian Institute of Biodiversity Conservation (2009) shows $213,464 \mathrm{~km}^{2}$ area of land is dedicated to wildlife conservation. Subsequently, current figure shows that a total of 15 per cent of the country's land is protected covering national parks, wildlife sanctuaries and reserves, controlled and open hunting areas and community conservation areas (Biodiversity Indicators Development National Task Force, 2010). However, most of these protected areas do not have legal status, and are inadequately protected. Even some of the gazetted, PAs are facing problems that could potentially deteriorate them (Ethiopian Institute of Biodiversity, 2014). Impoverished resource dependent local populations are still increasing in Ethiopia, both within and adjacent to national parks with high biodiversity value. 
Currently, around 320 species of mammals where 39 of them are endemic to Ethiopia, 918 birds with 19 endemic species, 240 reptiles of 16 endemics, 71 amphibians (30 endemics) and 172 freshwater fishes with 38 endemics and more than 1225 insects are recorded in Ethiopia (Wolff, 1961). Furthermore, Ethiopia is endowed with 21 national parks, 3 wild life sanctuary, 3 wild life reserves, 18 controlled hunting areas, 7 open hunting areas, and 3 community conservation areas (young, 2012). Despite such rich resources, Ethiopian forest cover is declining from $47 \%$ to $3 \%$ for the past few decades where Protected Area's covers $17.1 \%$ of land (Amare, 2015). Ethiopia possesses considerable biodiversity and natural resources, as well as many endemic species; however, its wildlife conservation policy has changed with changing regimes. It has had, however, only limited success protecting some of these natural assets since establishing conservation and protected area program in 1965 , due to the country's prolonged engagement in various armed conflicts. Moreover, given the potential of the park and biodiversity, the extent of protected areas and biodiversity conservation of the country is negligible lacking protected area networks and management plans (Biodiversity Indicators Development National Task Force, 2010).

Even though the exclusionary policy is not completely changed in Ethiopia, to some extent, there is a paradigm shift towards community participation with practical manifestation in Ethiopian protected areas where the community is participant in various ways at different levels. The main objective of the study is to examine changes in protected area management of Ethiopia with an emphasis to community participation with a systematic review of available literature and field visit to some of protected areas in Ethiopia. Despite a little attempts to community based protected area management, the protected area management policy of Ethiopia is the conventional and exclusionary approach. An attempt made to incorporate community participation in Semien Mountains National Park, and Senkele Wild life Sanctuary should be expanded to other protected areas of the nation.

\section{Methods}

This study is based on thorough literature review. This paper synthesizes protected area management changes and its implication for community Based protected area management from historical perspectives .Relevant literatures to protected area management at national and global scales, Ethiopia's protected area management, development and conservation policy, reports and directives under different regimes from imperial regime to current regime were reviewed conceptually.

\section{Results and Discussion}

\section{Brief history of Protected Area Management and Changes in Ethiopia}

Being known by its oldest recorded formalized conservation effort in Africa, Ethiopia has a long history of conservation. The first recorded indigenous conservation oriented activity in Ethiopia took place during the reign of Emperor Zerea Yacob (1434-1468). However, Ethiopian Wildlife Conservation Organization (EWCO) was established in 1965 and formally recognized as an autonomous body in 1970 as governing body for protected area management as proclaimed in Negarit Gazeta in the year 1970. The EWCO's responsibilities during that period included establishing nine national parks, four wildlife sanctuaries, seven wildlife reserves, and 18 controlled-hunting areas between 1965 and 1980. It also was responsible for adopting and implementing a range of hunting and conservation policies, including the adoption of IUCN (the World Conservation Organization) protected-area descriptions and guidelines classified all national parks as "Strict Conservation Areas."

The EWCO followed exclusionary protected-area policy with the limitation of all kinds of human use except as required for the management of the wildlife and conservation (Jacobs and Schloeder, 2001) resulted controversy on a previously unregulated species and natural resources and required involuntary resettlement of indigenous peoples (Moore, 1982; Turton, 1987). Forceful and continual adherence to this exclusionary protected-area policy, in conjunction with a nationwide lack of basic development and a diversion of finances toward conflict, was the most significant factor contributing to the conservation program's lack of success (Jacobs and Schloeder, 2001). Most of the conservation areas were established during the socialist regime (1974-1991) characterized by low local level support for the government's policies, restricted utilization of environmental assets and forceful resettlement (Jacobs and Schloeder, 2001; Desalegn, 2001). Despite the establishment of PAs, conservation policy during the socialist regime had not provided any means for the locals to access the land and manage natural resources in protected areas. Besides, exclusionary protected area approach was adopted which was the most significant contribution to Biodiversity loss of the time. Contrarily, dispute over land use pattern, policy change for land tenure, changing community's role in conservation and mismanagement by conservation agencies contributes to failures to conventional conservation approaches.

Many protected areas have followed the exclusionary approach without considering the social, cultural and political issues (Andrade and Rhodes, 2012). On the other hand, as decentralization approach and concerns to biodiversity conservation, after the fall of socialist regime a new institution (Ethiopian Wild Life 
Conservation Authority) that works with institutions at regional level were created (Vreugdenhil et al,. 2002) with enactment of different wild life development policy and regulation. Prior to 1900, natural resource management in Ethiopia is characterized by Common property resources regimes (Ashenafi and Williams, 2005) where early conservation efforts establishing PA's, enacting laws and regulation and assessing wild life population (Moore 1982); however, the current regime adopted community participation in PA management (Tessema et al., 2010, Negarit Gazeta, 2008). For instance, the Ethiopian Wild life development, conservation and utilization regulation enacted by council of ministers No. 163/2008 stated as:

"Persons who were inhabitants of wildlife reserve prior to the date of its establishment, to continue residing therein (Article 3: b). cognizant to this, Article (4) states persons authorized to reside in a wild life reserve pursuant to sub-article 3(b) of this Article shall have the right to cultivate their land plots without expanding, to allow their domestic animals graze and water, and to undertake bee keeping therein; provided however, that if the organ administering the wildlife reserve wishes to further develop the area, the in habitants may be resettled elsewhere. Moreover, based on agreements made between national park or wild life sanctuary management and the surrounding communities, seasonal utilization of natural resource such as bee-keeping and honey harvesting, cutting and taking of forage and medicinal plant collection, may be permitted under controlled conditions (Article 2(e)."

Thus, those people dependent on natural resources has no ownership and little involvement in their management. Even though the regulation for Wild life development, conservation and utilization regulation $163 / 2008$ article 7 advocates the community participation to manage, develop and undertake development activities to the natural resources of wild life conservation areas.

Even though Ethiopia is endowed with cultural capital subjective to broad societal culture, institutions, and developments, the concept of establishing PAs and conservation practices is adapted from western conservation approaches. Although international conservation agencies have supported its wildlife management financially and technically, it has been the Ethiopian government that mainly planned its conservation policy (Nishizaki, 2004). Indeed, there are a number of cultural capitals, traditional institutions, and indigenous knowledge's to be utilized. Different people in Ethiopia have a strong affiliation with nature even dependent on nature for survival. On the other hand ,the conservation models adopted by the three successive regimes in Ethiopia lacks the home grown development paradigms and relegated local values and contexts, genuine participation of the subjects for whom development paradigm were presumably borrowed (Regassa, 2012; Mark,2009).

\section{From "People out “PA Management Model to Community Based Protected Area Management in Ethiopia?}

At the beginning of $19^{\text {th }}$ century, the goals of conservation and the interests of local communities were considered as opposite to each other (Kelboro and Stellmacher, 2012) despite protected area's role as a foundation for biological diversity and development strategy (Howard et al., 2000; Wilkie et al., 2006). The recognition for community's participation in protected area of Africa is recognized by researchers in 1960's and 1970's despite over land use between local people and conservation agencies (Nishizaki, 2004). Moreover, there has been a paradigm shift in protected area management from exclusionary model to co-management (Phillips, 2003). As a social institution and political construct, it both attracts and evicts people, changes relative prices, constrains resource access and alienates people from nature and alters rights and power relations (Vedeld et al., 2012). Although parks have become the primary instrument for biodiversity conservation, it can inspire exaggerated land use and landscape fragmentation in surrounding landscapes (Hartter et al., 2011). On the other hand, urgent appeals to human rights concerns and equity have pushed a more people centered paradigm for parks (Langton et al, 2005).

When local communities are excluded from PA management, their needs and aspirations are ignored, it becomes extremely difficult to enforce conservation policies (Aswani and Weiant, 2004) resulted in biodiversity loss and an adverse impact on the well being of people. In areas where protected species co-exist with the ever increasing pressures of human expansion and anthropogenic change, biodiversity conservation often relies on local perceptions of the economic benefits and losses associated with wildlife protection (Ninan, Jyothis, Babu, \& Ramakrishnappa 2007). The development of protected areas has often been influenced by political factors (Joppa and Pfaff, 2009). Parks and other protected areas are established to solve challenges of biodiversity conservation, secure other environmental services and contribute to local livelihood improvements (Vedeld et al., 2012). With the establishment of Yellowstone National Park in the USA in 1876, an ideology of strict and isolated conservation that excluded local people and all forms of local participation in PAs took shape. This ideology gained popularity in several other countries, especially developing countries. In this model, people were generally excluded from PAs so as to leave nature undisturbed. This "people out" model effectively protects significant core landscapes within PAs, but overlooks ecological and socioeconomic flows within and 
outside of the boundaries of PAs (Palomo et al., 2013). Besides; dispute over land use between the local people and wildlife conservation agencies is becoming a serious problem in developing countries. It has now reached crisis levels in some areas where the local people used to utilize land until they were declared conservation areas. Recently there is an increase in disputes over land-use caused by combined factors such as expansion of cropland, policy change for tenure, and mismanagement by the conservation agency (Nishizaki, 2004). Further, creating parks has sometimes undermined local incomes and security, particularly in Africa where they are associated with exploitative colonial regimes.

The Ethiopian national parks, however, are characterized by exclusive conservation approaches, little effectiveness, and conflicts between local people living in or adjacent to the parks and state Regassa, 2012). Furthermore, as Adams and Hutton (2007) stated; "parks tend to reproduce existing economic inequalities within local communities and wider societies". But, exchange theory dictates that rational humans base their behavioral choices on maximizing gains and minimizing costs (Shogren et al., 1999), implying that if local people benefit from the existence of a PA, they will support conservation and the continued existence of the PA (Mackenzie, 2012); enable in strengthening local institutions for resource use and management; making them better decision maker and resulting in fundamental changes in power. Between the year 1966 and 2010 , the largest portion of protected area in Ethiopia is covered by Open hunting area (55\%) and $1 \%$ of it is covered by community conservation area (Biodiversity Indicators Development National Task Force, 2010). Ethiopia established 21 national parks, two sanctuaries, three wildlife reserves, 20 controlled hunting areas, six open hunting areas, six community conservation areas and 58 national forest priority area of which 37 are protected forests (Ethiopian Biodiversity Institute, 2014). A substantial change in the park organization and management culture is also necessary, in terms of changing attitudes, values and norms (Vedeld et al, 2012). Before 1990, the PA management philosophy of Ethiopian was 'park without people' approach (Hurni et al., 2008). In the present regime, in contrarily to socialist regime, there is benefit sharing mechanism and participation opportunities in ecotourism activities; mobilization of financial contributions and labor to support the development of the wildlife conservation area, and determine utilization preferences in consultation with the relevant organ of the regional government according to wild life conservation, development and utilization policy. As a result, effective biodiversity protection and improved human welfare as 'Win Win' situations have been the foundation for protected areas and conservation incentives (Kark, 2013). Beyond the physical development, utilization of indigenous knowledge, incorporation and encouragement of traditional institutions in protected area management, and assurance of their participation at different level is very low limited to few protected areas of Ethiopia comparable to its potential.

To ensure long-term success of conservation efforts supportive relationship between communities and protected area nearby is crucial; however failure to ensure participation of locals; absence of alternative livelihood and widespread poverty, human settlement, grazing, absence of legally recognized boundaries of protected areas were persistent in Ethiopian protected area (Environmental Protection Authority, 2003) where local community used to utilize the land until they were declared protected areas . It is legally recognized that the community can develop a community conservation areas and can be beneficiary from ecotourism development in the park and its surrounding where community based ecotourism is developing in Ethiopia showing changes from exclusionary approach to community based conservation approach. Even though not capitalized in all protected areas of Ethiopia, experiences from Semien Mountains' national park community based tourism, and Senkele wild life sanctuary's gada system's role as traditional institution in settling conservation problem can be an indicator of the effectiveness of Community based conservation approach in Ethiopia. The community based tourism development is the result of the ineffectiveness of exclusionary approach of protected area management in Ethiopia where people were expelled from Simien Mountains National Park (SMNP); the only national park registered as World heritage in Ethiopia by UNESCO in 1976 and difficulties phased.

Located in North Western part of Ethiopia, Semien Mountains National park is the first and the only national park in Ethiopia inscribed as World Heritage list in 1978 and was inscribed on the list of world heritage Danger in 1996. When it was Gazetted in 1969, there were 30 villages in the park and around the park of which two of them completely located in the park with a total of 28,000 people live in and around the park (IUCN, 2000). Accordingly in 1978, a large number of inhabitants were expelled with in the vicinity and inside the park, but many of them returned after eight year (in 1986) with limited use of resources in the park resulted in hostile relationship between the park management body and the community led to violent conflict before 1990 where park authorities were forced out from the park for around 10 years made conservation difficult; however, after the fall of socialist regime, benefit-sharing was introduced for some inhabitants of the villages along the tourist routes (Hurni et al., 2008). The number of Walia Ibex is increasing from 150-200 individuals in the last two decades before 2010 and estimated to be 700 in 2010). Local communities are linked to the administration of SMNP through local administrative structure (Hurni et al, .2008) but when initiated as a protected area by UNESCO mission in 1965, it was focused on exclusive protection of wild life without taking 
into account human factors. Moreover, the SMNP were experienced armed conflict during the fall of derg regime serving as a military base in the area caused a death of different wild life (Hurni et al., 2008). Community engagement in tourism started at the end of 1995 by shift but fees were collected by park officials and redistributed to the community indirectly by the park officials led to conflict where people lost the power to control and own the resources (Hurni et al.,2008) but later decentralized (Hurni ,2005). However, the startup for the engagement of the local communities in development of community based tourism with clear benefit sharing and auditing mechanism, there is a significant change in biodiversity conservation and change in community attitude towards the park.

Moreover, the changes from conventional protected area management to co-management with the local community are also magnified in Senkele Wild Life Sanctuary inhabited by endangered Swayne's hartebeests. The data in 974 shows that the relocation of Swayne's Hartebeests were considered as an alternative to ensure their survival where 90 of them were relocated to Nechisar national park and 120 of them were relocated to Awash national park (Lealem, 1974; Kumsa and Bekele, 2013). As a result, the number of Swayne's Hartebeests was increased from 448 to 2379 in the year 1976-1988 (Mattravers \& Netsereab, 1994); However, the number of Swayne's decreased to 123 in 1998 (Nishizaki, 1999). Indeed, only 40 of them were confirmed to inhabit Nechisar National Park (Duckworth et al., 1992). However, the translocation of Swayne's from the original place was ineffective. Moreover, due to country's experiences of armed conflict in previous regimes and development of negative attitudes towards conservation practices and benefits gained from development nearby the PA, the history of Senkele Wild life Sanctuary shows changes from Exclusionary approach to capitalization of traditional institutions as a solution of tragedy of the commons. As a result of effective of utilization of Gada system as collective measure with strict rules and regulation, the number of Swayne's in Senkele wild life sanctuary is increasing (from70 to 800 in the Ethiopian Herald report of 2015). If people get an opportunity to share their opinions on conservation and the process to do so is created for them, it leads to the better understanding of values, attitudes and the potential to find solutions to conflicts (Young et al., 2016). Moreover, the utilization and capitalization on what community can do and how they dealt with nature for years is very important.

According to a new regulation, having the right to live in the PA's of Ethiopia if settled before the establishment of the park, limited use of resources of the park, voluntary and involuntary resettlement if the land is required for further development; the approach to participatory protected area management is insignificant at policy level but further effort is made in some of PA management like SMNP and Senkele Wild life sanctuary. Therefore, a road map to participatory PA management needs clear policy statement and regulation as the new regulation enacted shows us the protectionist approach with little participation of the community.

\section{Conclusion}

Recognition of the relationship between local community and natural resource is very important in sustainability of protected area management and conservation goals where long standing tensions over land use, local utilization of nature, failed consideration to traditional resource usage and human wild life conflict may limit the local acceptance of conservation strategies. Moreover, Ethiopian protected area management and conservation strategies change with the change in political ideology and in regime. Despite changes in regime and changes in PA management philosophies, currently an attempt to promote and allow community participation should be considered. Notwithstanding with this, tragedy of the common is common in Ethiopian PA's but few concern is given for collective action with strengthening traditional institutions with strict rules and regulations.

\section{References}

[1]. Adams, W.M., \&Hutton, J. (2007). People, parks and poverty: political ecology and biodiversity conservation. Conservation and Society 5 (2), 147-183.

[2]. Agence française de développement (2014). Protected areas for biodiversity conservation and development

[3]. Agrawal,. A. and Redford, K.(2009). Conservation and Displacement: An Overview. Conservation and society, 7(1), 1-10

[4]. Andrade, G. S. M., and J. R. Rhodes. (2012. Protected areas and local communities: an inevitable partnership toward successful conservation strategies? Ecology and Society, 17(4):14. http://dx.doi.org/10.5751/ES-05216-170414

[5]. Ashenafi, Z. T., and N. Leader-Williams. (2005). Indigenous common property resource management in the Central Highlands of Ethiopia. Hum. Ecol, 33(4):539-563

[6]. Aswani, S., and P. Weiant. (2004). Scientific evaluation in women's participatory management: monitoring marine invertebrate refugia in the Solomon Islands. Human Organization, 63(3):301-319.

[7]. Barber ,C.V., Miller, K.R. and Boness .M .(2004).Gland, Switzerland and Cambridge ,UK: IUCN

[8]. Biodiversity Indicators Development National Task Force (2010). Ethiopia: Overview of Selected Biodiversity Indicators. Addis Ababa. Pp. 48

[9]. Brockington, D., Duffy, R., \& Igoe, J. (2008). Nature unbound: Conservation, capitalism and the future ofprotected areas. London: Earthscan.

[10]. Brockington, D., Holmes, G., (2010). Presentation in Chronic poverty seminar Manchester 8 
[11]. Cleaver F. (1999).Paradoxes of participation: questioning participatory approaches to development. Journal of International Development, 11(4),1597-612

[12]. Dessalegn, R. (2001). Environmental change and state policy in Ethiopia: lessons from past experience. Forum for social studies monograph Series 2. Addis Ababa. Ethiopia.

[13]. Du,W., Penabaz-Wiley, S.M , Murithi Njeru, A,. \& Kinoshita, I. (2015). Models and Approaches for Integrating Protected Areas with Their Surroundings: A Review of the Literature; Sustainability, 7, 8151-8177

[14]. Duckworth, J.W., M.I. Evans, R.J. Safford, M.G. Telfer, R.J. Timmins \& C. Zewdie,. (1992). A Survey of Nechisar National Park, Ethiopia: Report of the Cambridge Ethiopia GroundWater Forest Expedition 1990. International Council for Bird Preservation Study Report No.50, U.K.

[15]. Environmental Protection Authority (2003). State of the Environment Report of Ethiopia. Addis Ababa ,Ethiopia

[16]. Ethiopian Biodiversity Institute (2014). Ethiopia's Fifth National Report to the Convention on Biological Diversity. Addis Ababa, Ethiopia

[17]. Fabricius ,C. (2004). The fundamentals of community based natural resource management. In Rights, Resources \& Rural Development: Community-based Natural Resource Management in Southern Africa, Fabricius C, Koch E (eds.). Earthscan, 3,43

[18]. Gebremedhin,B., Gentile, F., Flagstad O., \& Taberlet, P., (2010). Demography, distribution and management of walia ibex (capra walie). Galemys 22 ( $\mathrm{n}^{\circ}$ especial), 421-432,

[19]. Goldman,M .(2003). Partitioned Nature, Privileged Knowledge: Community-based Conservation in Tanzania. Development and Change ,34(5), 833-862

[20]. Hartter,J., Goldman, A.,\& Southworth,J. (2011). Responses by households to resource scarcity and human-wildlife conflict: Issues of fortress conservation and the surrounding agricultural landscape. Journal for Nature Conservation, 19, 79-86

[21]. Howard, P., Davenport, T., Kigenyi, F., Viskanic, P., Baltzer, M., Dickinson, C.1. (2000).Protected are aplanninginthetropics: Uganda' snational system of forest nature reserves. Conservation Biology, 14(3), 858-875.

[22]. Hurni, H,, Abunie,L., Ludi, E.,Woubshet,M. (2008). The evolution of institutional approaches in the Simen Mountains National Park, Ethiopia. In: Galvin M, Haller T, editors. People, Protected Areas and Global Change: Participatory Conservation in Latin America, Africa, Asia and Europe. Perspectives of the Swiss National Centre of Competence in Research (NCCR) North-South, University of Bern, 3, 287-323.

[23]. Hurni, H. (2005). Decentralized Development in Remote Areas of the Simen Mountains, Ethiopia. Dialogue Series. With map, scale 1:250,000. Bern: NCCR North-South, 45 pp.

[24]. IUCN (2000). Indigenous and Traditional Peoples and Protected Areas Principles, Guidelines and Case Studies. Best Practice Protected Area Guidelines Series No. 4

[25]. J. C. Young ,Searle.,K., Butler .A., Simmons.P ., Allan D. Watt ., and Jordan.A.(2016). The role of trust in the resolution of conservation conflicts. Biological Conservation, 195, 196-202

[26]. Jacobs, M J., and Schloeder. CA.,(2001). Impacts of Conflict on Biodiversity and Protected Areas in Ethiopia. Washington, D.C.: Biodiversity Support Program.

[27]. Jacobs, M J., and Schloeder. CA., (2006). Impacts of Conflict on Biodiversity and Protected Areas in Ethiopia. Grammarians, Inc.

[28]. Joppa, L.N., and Pfaff, A., (2009). High and far: biases in the location of protected areas. PLoS One 4, e8273

[29]. Juliette C. Young, Kate Searle, Adam Butler, Peter Simmons, Allan D. Watt, Andrew Jordan (2016). The role of trust in the resolution of conservation conflicts Biological Conservation, 195, 196-202

[30]. Karki, S.T.(2013). Do protected areas and conservation incentive s contribute to sustainable livelihoods? A case stud y of Bardia National Park, Nepal. Journal of environmental management, 128, 988-999

[31]. Kelboro,G., \& Stellmacher,T. (2012). Contesting the National Park theorem? Governance and land use in Nech Sar National Park, Ethiopia. ZEF Working Paper 104

[32]. Kumssa,T \& Bekele,A. (2013). Human-wildlife conflict in senkele swayne's hartebeest sanctuary, Ethiopia. Journal of Experimental Biology and Agricultural Sciences, 1 (1):33-38

[33]. Langton,M., Ma R.Z., Palmer, L. (2005). Community-Oriented Protected Areas for Indigenous Peoples and Local Communities. Journal of Political Ecology, 12, 23-50

[34]. Lealem B. 1974. Operation Swayne's hartebeest. Orix, 12,556-558

[35]. Mackenzie. C.A. (2012). Accruing benefi t or loss from a protected area: Location matters. Ecological economics, 76:119-129.

[36]. Marcia, J., Langton., Rhea., Z.M., and Palmer,L,. (2005). Community-Oriented Protected Areas for Indigenous Peoples and Local Communities. Journal of Political Ecology, 12, 23-49

[37]. Mark ,D.(2009).Conservation Refugees: The Hundred-year Conflict between Global Conservation and Indigenous Peoples. Massachusetts: Massachusetts Institute of Technology

[38]. Mattravers M. \& B. Netsereab (1994). The Senkelle Swayne's Hartebeest Sanctuary Management Plan. EWCO, Mimeo, Addis Ababa.

[39]. Moore, G. (1982). Forestry, Wildlife and National Parks Legislation in Ethiopia. FAO, Assistance to Forestry Research, Phase II. FO:DP/ETH/78/012, Rome. 53 pp

[40]. Naughton-Treves,L,. Holland,M.B,. And Brandon ,K., (2005).The Role Of Protected Areas In Conserving Biodiversity And Sustaining Local Livelihoods. Annual Review of Environment And Resources, 30, 219-252. Doi: 10.1146/Annurev.Energy.30.050504.164507

[41]. Naughton-Treves,1,. Margaret B. Holland,, Brandon,K. (2005).The role of protected areas in conserving biodiversity and sustaining local livelihoods. Annu. Rev. Environ. Resource,. 30,219-52

[42]. Negarit Gazeta (2008). Ethiopian Council of ministers regulations to provide for wildlife development, conservation and utilization . Council of Ministers Regulations No. 163/2008

[43]. Negera,A.(2009). Resettlement and Local Livelihoods in Nechsar National Park, Southern Ethiopia. Unpublished MPhil Thesis, University of Troms $\emptyset$,

[44]. Ninan, K. N., Jyothis, S., Babu, P., \& Ramakrishnappa, V. (2007). The economics of biodiversity conservation: Valuation in tropical forest ecosystems. UK: Cromwell Press.

[45]. Nishizaki,N. (2004). Resisting imposed wildlife conservation: Arssi Oromo and the Senkelle Swayne's Hartebeest sanctuary, Ethiopia. African Study Monographs, 25(2): 61-77

[46]. Oates, J. F. (1999). Myth and Reality in the Rainforest: How Conservation Strategies are failing in West Africa. Berkeley, California: University of California Press.

[47]. Ostrom, E. (1990). Governing the Commons: The Evolution of institution for Collective action. Cambridge University press

[48]. Palomo, I., Martín-López, B., Potschin, M., Haines-Young, R., and Montes, C. (2013) National Parks, buffer zones and surrounding lands: Mapping ecosystem service flows. Ecosyst. Serv, 4, 104-116 
[49]. Phil lips, A. (2003). "Turning ideas on their head: the new paradigm for protected areas". The George Wright Forum, 20 (2).

[50]. Regassa,A. (2012). Contesting Views on a Protected Area Conservation and Development in Ethiopia. soc. Sci, 1, 24-46

[51]. Roe, D,. Nelson ,F., \& Sandbrook,C. (2009 eds.). Community management of natural resources in Africa: Impacts, experiences and future directions. International Institute for Environment and Development, iied, UK

[52]. Shogren, J.F., Tschirhart, J., Anderson, T., Whritenour-Ando, A., Beissinger, S.R., Brookshire, D., Brown Jr., G.M., Coursey, D., Innes, R., Meyer, S.M., Polasky, S., (1999). Why economics matters for endangered species protection. Conservation Biology 13, $1257-1261$

[53]. Terborgh, J., and M. E.Soule. (1999). "Why We Need Megareserves: Large-Scale Reserve Networks and How to Design Them.” In Continentall Conservation, ed. M. E. Soule and J. Terborgh, 199-209. washi intton? D.C.: Island Press.

[54]. Tessema, Mekbeb E., Lilieholm, Robert J., Zelealem A., and Williams .1., Nigel. (2010). 'Community Attitudes toward Wildlife and Protected Areas in Ethiopia', Society \& Natural Resources, 23(6):489 - 506

[55]. Turton, D. (1987). The Mursi and National Park Development in the Lower Omo Valley. In D. Anderson and R. Grove, eds, Conservation in Africa: People, Policies and Practice, 169-186. Cambridge: Cambridge University Press.

[56]. Vedeld,P. , Jumane ,A., Wapalila, G. , \& Songorwa,A. (2012). Protected areas, poverty and conflicts: A livelihood case study of Mikumi National Park, Tanzania. Forest and policy economics, 21, 20-31

[57]. Vreugdenhil.,D,. A. M,. Vreugdenhil,. Tilahun .,T, Shimelis.A,. Tefera Z,.(2012). Gap analysis of the protected areas system of Ethiopia. SDPASE project report

[58]. West,P., Igoe ,J.,\& Brockington,D.(2006). Parks and peoples: the social impact of protected areas. Annual review of Anthropology, 35, 251-277

[59]. Wilkie, D. S., Morelli, G. A., Demmer, J., Starkey, M., Telfer, P., \& Steil, M. (2006). Parks and people: Assessing the human welfare effects of establishing protected areas for biodiversity conservation. Conservation Biology, 20(1), 247-249

[60]. Wolff, J.V. (1961) Wildlife in Ethiopia. Ethiopian Forestry Review, 2, 3-13

[61]. Young, J. (2012) Ethiopian Protected Areas: A "Snapshot". Word Press, Addis Ababa, 23. 